\title{
Intermédialités
}

Histoire et théorie des arts, des lettres et des techniques

Intermediality

History and Theory of the Arts, Literature and Technologies

\section{Radio as Music. A Video Document by (and with) Glenn Gould}

\section{Philippe Despoix}

Numéro 19, printemps 2012

URI : https://id.erudit.org/iderudit/1012663ar

DOI : https://doi.org/10.7202/1012663ar

Aller au sommaire du numéro

Éditeur(s)

Revue intermédialités (Presses de l’Université de Montréal)

ISSN

1705-8546 (imprimé)

1920-3136 (numérique)

Découvrir la revue

Citer cet article

Despoix, P. (2012). Radio as Music. A Video Document by (and with) Glenn Gould. Intermédialités / Intermediality, (19), 177-180.

https://doi.org/10.7202/1012663ar d'utilisation que vous pouvez consulter en ligne. 


\title{
Radio as Music
}

\section{A Video Document by (and with) Glenn Gould}

\author{
Philippe Despolx
}

F

ew artists have ventured as far as Glenn Gould in the search for an increasingly close-knit relation between sound reproduction technologies and the control of aesthetic production. For Gould, as is widely known, the concert hall soon ceased being an adequate venue for such an undertaking. But the Toronto native's legendary decision to renounce public concerts, as of 1964, exclusively in favour of the recording studio, was part of a wider experimental reorientation toward electronic broadcasting media. From the 1960s onward, and parallel to his studio work in pianistic recording, Gould began to produce a series of radio and television programs for the $\mathrm{CBC}$ which are still relatively unknown outside of Canada. It is primarily through these media and their technical evolution that Gould was able to strengthen his position as a producer, leading him to develop a new form of composition in the process. The previously unpublished conversation presented here is taken from an unedited video documentary, Radio as Music, which Gould produced in 1975." This document shows Gould explaining his programmatic vision of the specificities of radio musicality from within the studio. It also provides unique insight into the composer's pioneering role as an intermedial artist using video techniques.

It is worth remembering the importance of Gould's correspondence with Marshall McLuhan, beginning precisely in 1964 with the publication of Understanding Media, in the development of Gould's own conception of technology. This exchange led to McLuhan's participation in Dialogues on the Prospects of Recording, a radio piece Gould produced for the CBC the following year. For this piece, Gould combined interview fragments celebrating the ubiquity of technical reproduction with other ones which, on the contrary, deplored losing the immediacy of the concert situation. This polyphonic "dramatization" of questions arising from the generalization of high fidelity also led to the publica-

"We wish to thank Mario Gauthier for calling our attention to this important document, which had heretofore failed to attract scholarly attention. 
tion of Gould's seminal text, "The Prospects of Recording” (1966), which can be construed as a pendant of sorts to Benjamin's reflection on the work of art in the era of its technological reproducibility. ${ }^{1}$ Gould seems to have made radio an experimental field for his textual production of the 1960 s and 70 , which was largely based on pre-scripted programs, as in the previous example and also in his essays on Petula Clark or Stokowski. ${ }^{2}$

The studio production of his multivocal interviews also might have led Gould, who remained obsessed with the extension of our listening abilities, to conceive of the series of radio documentaries on the Canadian North that eventually composed his Solitude Trilogy. The first of these experimentations, The Idea of North, was produced in monophony in 1967; the second, The Latecomers, inaugurated the new stereophonic program of Ottawa's CBO-FM in 1969; finally, Quiet in the Land, the most complex of the three, was completed and broadcast in 1977. All three pieces exemplify what Gould called the "contrapuntal documentary," in which recorded voices, sounds and music are combined into a new genre that blends the pre-existing categories of documentary, composition and polyphony.

After the first two episodes, Gould decided to add a television adaptation of The Idea of North; this was produced by Judith Pearlman and broadcast under the same title in 1970. The following year, Gould published "Radio as Music," his programmatic conversations with John Jessop, which are primarily concerned with the expressive possibilities of radio. Gould points out how the temporal constraints of radio production simply led him to salvage sections of recorded material by superimposing different voices. In this interview, he also underlines the need to experience a "slow, grudging acknowledgment of the medium" at each step of its evolution. ${ }^{3}$

1. See Glenn Gould, “The Prospects of Recording,” High Fidelity, April 1966; reprinted in Tim Page (ed.), The Glenn Gould Reader, New York, Random House, 1984, p. 331-353.

2. To cite only a few pieces among Gould's important radiophonic production that led to written publications, see: "The Search for Petula Clark," High Fidelity, 1967; "Stokowski in Six Scenes," Piano Quarterly, 1977-78; reprinted in ibid., p. 300-307 and p. 258282 respectively.

3. See "Radio as Music," in The Canadian Music Book, Spring-Summer 1971; reprinted in ibid., p. 388 for the citation. These interviews are in the lineage of Rudolf Arnheim, Radio: An Art of Sound [1936], Salem, Ayer Company Publishers, 1986; Pierre Schaeffer, Essai sur la radio et le cinéma. Esthétique et technique des arts-relais 1941-1942, Paris, Allia, 2010. Copies of the document are held in the CBC's Archive in Toronto and at the now defunct Phonothèque Québécoise (Montréal). 
Below is a transcript of the opening of a video document of the same title, Radio as Music, which features a conversation with John Thompson. The video, which was never completed or released, was privately produced by Gould on August 29, 1975 in the CBC's studios, most likely in anticipation of the International Exhibition of Music for Broadcasting in Toronto. The first section of the tape, the only one which was edited, documents a studio session in which Gould and his collaborator, Donald Logan, are mixing the radio piece Quiet in the Land. Then, freelance producer John Thompson asks Gould a series of questions pertaining to the "contrapuntal radio documentary." Radio as Music is a unique document, not only because Gould makes the conception process behind his technique explicit, but also because he comments on his concrete production method by providing a greater understanding of its consequences in "musical" detail. We are granted entry into the composer's studio, where reproduction via multitrack recorder morphs into a medium of musical production: Gould creates with the technician, and recreates for his guest, John Thompson, the gestures which preside over montage and the mixing of tracks and, ultimately, over the contrapuntal synchronization of his material.

Gould's key concepts include the complexification of polyphonic assembly and control of the temporal line, in his words, "right to the heartbeat"- both are made possible by the evolution of the technical medium. If Gould's contrapuntal radio practice began with the monophonic piece The Idea of North, it comes fully into its own in the stereophony of the radiophonic trilogy's subsequent episodes, as is made evident through a comparative aural study of the three pieces. The process of specific sound spatialization is being put to work here with Donald Logan: following a transcript which works as a score, Gould, chronometer in hand, leads Logan to experiment with a montage of multiple voices and noises for a scene in The Mennonites (the working title of the last episode of the trilogy). It is this work of track synchronization, effected on the raw recordings, that provides the starting point for the exchange with Thompson.

The broadening of polyphonic organization, while using not only music, but linguistic material and environmental sound, is a consequence of truly recognizing the medial particularities of multitrack reproduction. Thus, it is unsurprising that Gould inserts his exploratory work in the tradition of technical mastery, in the sense of the Materialgerechtigkeit of the Second Viennese School and, more specifically still, as a continuation of the contrapuntal conceptions of Webern.

4. The document is mentioned in Réal La Rochelle, "Parcours québécois et canadiens en cinéphonographie," CiNéMAS, vol. 3, nº 1, p. 104. 
The extension of listening capacities promoted by Gould displaces the traditional category of counterpoint, and even that of musicality: it is the repetition, with a different timbre, of a sound entity-here a single word in an interviewwhich opens onto another vocal line and acts as a main element in the polyphonic dynamic. But this variation in enunciation occurs not only at the level of sound, but also semantically, ultimately provoking a dramatizing effect. Seeing and hearing Gould at work, it becomes clear that the timbre of voices, semantics, the prosody and rhythm of discourse, all contribute significantly to the structural decisions made in the final mix. ${ }^{5}$

It is noteworthy that Gould, in laying out his conception of the contrapuntal documentary in the interview, insists on parallelism between the mixing of vocal lines and images in the televisual adaptation of The Idea of North. ${ }^{6}$ One might even ask whether this unique transposition to video was not an a posteriori experimental way of supplementing the monophonic execution with spatial dimension. In any case, it is the very gesture of the technician at the mixing desk, which reproduces Gould's truly "orchestral" hand, that electronically fixes both the audio and video compositions. Through an association of the two processes, it becomes possible to pass from a monophonic voice trio to a sextet composed of both sounds and images. From this perspective, Gould's work can be characterized as an ensemble of constantly renewing techniques of dynamic intermediation: between score and recording, radiophony and writing, documentary and dramatic fiction, voices and multiple sounds, semantics and musicality, soundtracks and electronic images.

Translated by Caroline Bem

5. See Anthony Cushing, "Glenn Gould and 'Opus 2': An Outline for a Musical Understanding of Contrapuntal Radio with respect to The Idea of North," Circuit: musiques contemporaines, vol. $22, \mathrm{n}^{\circ} 2,2012$ (in press).

6. Subsequently, Gould returned to work in the medium of television (with Bruno Monsaingeon, amongst others) and reused some of the techniques described here. 